\title{
ע GENDERED NATIONALISM, NEO-NOMADISM, AND ETHNIC-BASED EXCLUSIVITY IN KYRGYZ, KAZAKH AND UZBEK NATIONALIST DISCOURSES
}

\author{
Fabio Belafatti \\ University of Groningen/Vilnius University
}

\begin{abstract}
Existing literature on gender and nationalism has postulated that nationalist narratives tend to convey patriarchal and restrictive views of gender roles, with women's domesticity and subordination at the core of such interpretations. This paper tests this theory by looking at three examples of state-sponsored or state-produced communication in Kazakhstan, Kyrgyzstan and Uzbekistan, arguing that the simple existence of a regime's nationalist ideological orientation is not per se sufficient to explain or anticipate the kind of gender narratives a regime will adopt. Instead, the paper calls for an analysis of internal political mechanisms and incentives in order to explain and anticipate the specific forms that discourses around gender may take in a given political environment. In order to do so, it makes a tentative effort to combine the rational choice-based "Selectorate Theory" (Bueno de Mesquita et al. 2003) with existing literature on nationalism and gender to define a connection between political systems on the one hand and discourses on the other.
\end{abstract}

\section{INTRODUCTION: GENDER AND NATIONALISM}

The consensus among scholars of gender and nationalism is that the image of women in nationalist narratives is generally constructed as passive, weak and subordinate to men (husbands, fathers) and traditional patriarchal rules of behaviour. Furthermore, women are deprived of control over their sexuality, which is generally seen not as a field of assertion of individual rights or personal choice, but as a tool in the service of the interests of the nation, particularly insofar as the idea of woman as child-maker, material "producer" of members of the nation, and a symbol of national virtue is concerned (Nagel 1998; Kandiyoti 1991; specifically on Central Asia, see Northrop 2004). It has even been argued that the gendered nature of nationalism is at the very core and foundation of the "us versus them" logic intrinsic in any nationalist narrative. In the words of Peterson (1994:83),

The gender hierarchy of masculine over feminine and the nationalist domination of insiders over outsiders are doubly linked. Nationalism is gendered in how the construction of group identity (allegiance to "us" versus "them") depends upon divisions of masculinity and femininity. In this sense, the process itself presupposes gendered social relations. Nationalism is also gendered in how the naturali-

Volume 7 (2019), pp. 66-81

DOI $10.23993 /$ store. 69958

Licensed under Creative Commons Attribution 3.0 License.

ISSN: 2323-5209

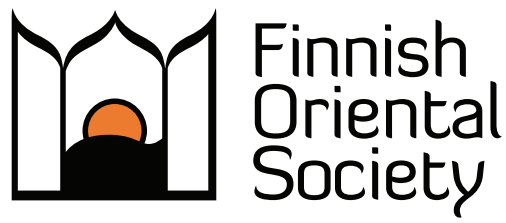


zation of domination ("us" at the expense of "them") depends upon the prior presumption of men/ masculinity over women/femininity. ${ }^{1}$

The gendered nature of nationalism has been explored and confirmed in a Central Asian context, too (Ishkanian 2004; Koch 2011; Thibault 2016; for a Mongolian context, see Billé 2015). ${ }^{2}$ The general discourse of female subordination/passivity versus male domination/activity has been pointed out with reference to the case of Uzbekistan by, among others, Megoran (2008), who, in an article regarding official narratives about the Andijan massacre, called for a muchneeded deeper analysis of the role of gendered narratives in shaping day-to-day deployment of the nationalist discourses adopted by Central Asian authorities. ${ }^{3}$ Within the framework of this debate, this paper tries to address the issue by exploring three examples of "gendered" nationalist narratives developed in Kazakhstan, Kyrgyzstan and Uzbekistan, highlighting the profound differences between the types of gender roles presented in the three cases, differences that appear to contradict the common academic consensus on the gendered nature of nationalism. It then seeks to suggest a potential explanatory framework to account for such divergences by looking at existing differences in the functioning of the three countries' political systems. In so doing, the paper proposes to shift the analysis towards the micro-level of specific political mechanisms within a political system, bearing in mind that a simplistic classification of political systems along a classical democracy-authoritarianism continuum might not be the ideal framework with which to look at the issue. Underpinning this research question is the belief that a correct identification of which political environments are more likely to construct diminishing gender discourses for women has potential practical applications in forecasting correctly the type of gender policies we can expect to develop, at any given time, within a certain socio-political context.

\section{KEY FEATURES OF CENTRAL ASIAN NATIONALIST DISCOURSES}

The broader literature about Central Asian nationalism has highlighted the importance of a few peculiar trends appearing in virtually every Central Asian state: first, the tendency to retroactively apply the analytical framework of the nation to a time when "nationality" was either nonexistent or not the main defining factor of people's identity; and secondly, a constant "quest for the state", namely, the desire to confirm the legitimacy of the nation-state by presenting it as "moral heir" to some ancient, glorious polity, carefully selected not on the basis of its historical or geographic similarity with the contemporary state but on its usefulness to further better the symbolic interests of the contemporary state (Adams 2010; Akbarzadeh 1996; Kurzman 1999; Fedorenko 2012). Within this framework, it is also possible to register another general trend in

1 Indeed, the connection between nationalist ideologies and a conservative, patriarchal view of women's role in society is almost intuitive. Within a post-Soviet context, a telling example is provided by former LTSR politician Kazimiera Prunskiene: in May 1992, in her effort to pander to nationalists and re-accredit herself as a patriotic leader following Lithuania's successful struggle for independence, she organized a conference on gender roles, which were presented according to extremely narrow patriarchal-nationalist ideas of women as a mere reproductive resource. Among the presentations at the conference, one warned that the "family is the social institution where women may express themselves. For fifty years [during the Soviet occupation] we lived in opened world and now we have many worries" (quoted in Lieven 1994:32).

2 The gendered nature of Central Asian nationalisms can be seen regardless of religious or ethno-linguistic backgrounds, as Billé's research on Mongolia and Thibault's work on Tajikistan show.

3 Megoran's $(2002 ; 2011)$ work focusing on the Kyrgyz-Uzbek border also deals with issues of gender and nationalism, particularly the gendered consequences of nationalist geopolitical decisions. 
Central Asia: the definition of narrowly-limited ethno-national interpretations of the "nation" as opposed to more flexible, inclusive, civic forms of national discourses (Fedorenko 2012; for the Kazakh context, see Kesici 2011; on Kyrgyzstan, see Megoran 2013; Laruelle 2012; Marat 2016). In line with this, it is easy to note in all Central Asian states (and, arguably, in most postSoviet countries) the emergence of an urgency to celebrate the nation's traditions and past, an urgency which, in the context of Kazakhstan and Kyrgyzstan, assumes forms of a "veneration" of the previously discredited nomadic past of the Turkic collectivities of the region. ${ }^{4}$ This form of "neo-nomadism" is absent, however, in the case of Uzbekistan, which frames its history of sedentary empires as a source of prestige for the contemporary state.

\section{CONNECTING NATIONALISM, GENDERED NARRATIVES AND POLITICAL SYSTEMS IN CENTRAL ASIA}

The literature about gender and nationalism reviewed above often operates with a limited focus on the features of the political system in which nationalist discourses around gender roles develop. While it is temptingly easy to draw a connection between totalitarian (fascist) political systems and restrictive understandings of women's role in society (the "cult of domesticity" in Germany, for example, as described by Gupta (1991)), ${ }^{5}$ the definition of a causal relationship, or at least a correlation, between political system and gendered nationalist discourses becomes more complicated if we broaden the analytical perspective. Other totalitarian regimes, such as the USSR, had a very different understanding of women's rights and profoundly different policies in this field (as contradictory as they may have been, especially with regards to the issue of the "double burden" for Central Asian women (Kandiyoti 2007)). When the USSR adopted nationalist narratives, these did not bring about a dramatic change in gender discourses. Despite the USSR's massive usage of tropes and symbols of "romantic nationalism" in the 1930s (Slezkine 1994) and, ${ }^{6}$ more specifically, what Martin (2001:270) described as "the rehabilitation of traditional Russian culture and Russian nationalism as a force for Soviet unity" to achieve a "nationalist revolution from above", the USSR remained committed to genderequal discourses, albeit with the well-known limitations of women's ability to access the upper echelons of the Party. The Second World War brought about both a colossal employment of symbols of Russian nationalism and a considerable mobilization of women, with Soviet female citizens serving on the frontline of the war effort itself.

Therefore, the emergence of a nationalist discourse within a totalitarian system does not seem enough to cause the development of patriarchal, diminishing, "domestic" gender narratives. Looking beyond totalitarianism, it is possible to see that democratic countries, too, were not completely immune from nationalist narratives that entailed restricted views of gender roles. Several of the masculinity-centred nationalist discourses that Nagel (1998) reviewed developed

\footnotetext{
4 Laruelle (2007) provides an interesting overview of the most radical forms of this tendency, visible among "political Tengrists".

5 I am following the classical Arendtian definition of totalitarianism as an ideology-powered form of socio-political organization, which is innovative and different from traditional tyranny, with identical features regardless of the totalitarian regimes' collocation on the Left-Right spectrum (Arendt 1962).

6 In particular, Slezkine (1994:446) writes that "the 1934 Congress of Soviet Writers, which in many ways inaugurated high Stalinism as a cultural paradigm, was a curiously solemn parade of old-fashioned romantic nationalisms. Pushkin, Tolstoy and other officially restored Russian icons were not the only national giants of international stature."
} 
precisely within the most democratic societies of the time, such as the late-nineteenth and early twentieth-century US and Great Britain. Moreover, masculinity appears routinely as a core component of nationalist and militarist discourses in democratic societies during WWI, when both British and American war propaganda showed forms of gender-based rhetoric that differed little from those that fascist regimes would use a few years later (or those that Megoran (2008) identified in authoritarian Uzbekistan): emphasis on the postulated connection between masculinity and strength; the idea of women as weak, submissive, passive and in need of protection; the construction of female virtue as a symbol of national honour; and mechanisms of shame for men refusing to do their military duty for the nation (Fox 2014a; 2014b; Ormiston \& Sheffield 2013). ${ }^{7}$ As the overview of the three examples from Kazakhstan, Kyrgyzstan and Uzbekistan will show, the existence of a nationalist narrative itself does not per se automatically imply the existence of reductive gender discourses.

It is therefore clear that the usage of classical political science categories such as "democracy", "authoritarianism" or "totalitarianism" is not sufficient to discern patterns and anticipate tendencies in the development of gendered nationalist discourses. ${ }^{8}$ As will be shown below, things become even more complex if we include Central Asian states in the equation, unless we take into consideration more precise factors beyond the simple definition of regime type. I argue that the successful identification of patterns in nationalist narratives requires going beyond definitions. Instead it entails a detailed analysis of the practical functioning of political systems and the power mechanisms that guarantee regime survival. Whereas accounts of nationalism in Central Asia do focus on the role of regime survival in shaping nationalist narratives, the existing literature on the relation between gendered narratives and nationalism tends not to focus on such factors as the practical functioning of a polity, specifically regarding what concerns the existence of political incentives and rational choice as shapers of public policies. Nationalism is invariably seen as "gendered", whether it develops within a democratic or a nondemocratic society, or whether the society's political organization creates the incentives for this or not. On the other hand, political science literature that revolves around rational choice theories tends to focus overwhelmingly on the material dimensions of political decision-making and tends to miss out on the importance of non-material elements such as ideology, narratives, legitimacy and the role of hegemonic discourses in sustaining power structures, ${ }^{9}$ especially vis-à-vis oft-neglected topics such as gender.

This paper argues that a combination of rational choice theory and analysis of discourses and nationalism can offer a key to a better understanding of contemporary Central Asian nation-

\footnotetext{
7 Fox (2014b) presents an interesting "nationalist moral dilemma" related to the concept of women as the "womb of the nation" in democratic France's war propaganda; with reference to French women raped by German soldiers, and in a clear case of construction of the image of women as a property of the nation, the following question arose: "Could the 'child of the barbarian' ever be raised as a Frenchman, and, if not, would the State and the Church sanction abortion to remove the enemy foetus not only from the violated woman but also from the entire body politic?"

8 The reference here is to frequently used categories such as Freedom House's "consolidated democracy""consolidated authoritarianism" scale (Freedom House 2012) or Polity IV's classification along a "full democracy"-“autocracy” scale (Marshall \& Gurr 2013).

9 With reference to hegemonic discourses about gender, I am following the approach delineated by Stoddart (2007) in his review of theories of knowledge and power, in the belief that, differently from Marxist, critical and post-structuralist theories, "the ongoing work of theorists of gender and 'race' [...] offers a more complex understanding of how our consent to power is produced within contemporary capitalist societies" (Stoddart 2007:222). For a critical perspective on the whole concept of "hegemonic discourse", see Jenson 1994.
} 
alism. As a case study, this paper will apply "gendered nationalism" theory to the Kyrgyz movie Kurmanjan Datka: Queen of the Mountains by Sadyk Sher-Niyaz, comparing it, on the one hand, with the Kazakh video and photo essay How Kazakh Military Women Changed in 550 Years?, issued as part of the PR work of the Ministry of Defence of Kazakhstan, and, on the other hand, with the recent trends in Uzbek cinematography analysed by Polak (2015). In particular, I aim to show that while the focus on nationalism and public discourses is an excellent tool to explain the existence of nationalist messages in state-supported cinema or PR videos, in and of themselves they are not enough to explain why a narrative acquires a certain form instead of another. For this reason, I combine an analysis of literature about nationalist discourses with the rational choice theory of political science, with the hope of clarifying the reasons behind the selection of specific forms of discourse with regards to gender and nation.

\section{THE CASE OF KURMANJAN DATKA: QUEEN OF THE MOUNTAINS (2014)}

Produced over a period of three years and released in 2014, this movie tells the story of Kurmanjan Datka, a woman who took command of the Kyrgyz tribes in the Kokand khanate and would later guide their struggle against the Russian colonial invaders (Pannier 2014). A significant part of the funding came - controversially - from taxpayers, allowing for the creation of the most expensive Kyrgyz movie ever made. According to Ibraimov (2014), the movie was made in an attempt to "bolster patriotism": MP Zhyldyz Zholdosheva of the nationalist Ata-Zhurt party, loyal to the former ultra-nationalist president and strongman Kurmanbek Bakiyev, developed the initial idea and, allegedly, personally selected the director. A version with English subtitles was then produced and presented at international festivals, where it received praise from Western actors and moviemakers (Canning 2014; Ibraimov 2014; Lelik 2014). The heavy involvement of politicians and institutions, the alleged hand-picking of the director by a major politician, and the movie's semi-official role as promoter of Kyrgyzstan's image abroad support analysis of Kurmanjan Datka as a political tool and expression of a political discourse, rather than just an example of cinematography, as would be the case had it been produced independently, without any support or involvement from politicians or institutions. As far as topics and themes are concerned, the movie can be characterized as an interesting intertwining of two different tales: one of strict, exclusive ethnocentric nationalism, featuring an implicit antiminorities rhetoric and a celebration of traditional nomadic way of life of the Turkic peoples; and a second one which, contrary to what we would expect on the basis of existing literature on gendered nationalism, focuses on female empowerment, challenges to traditional gender roles, celebration of "non-virile" values, and the possibility for women to rise to the top of political power structures within nomadic Turkic societies.

\section{Main themes}

National identity, celebration of nomadism and ethnonational exclusivity

The brand of national identity presented in Kurmanjan Datka is a strictly ethnocentric one, and it features all of the aforementioned characteristics of contemporary Central Asian nationalism: 
the idea of an ancestral state; the concept of an ancient, "persecuted nation"; ${ }^{10}$ and the definition of clear-cut and irreconcilably different ethnic groups in an oversimplified version of history that glosses over the mixing and ambiguity of different ethnic groups and lifestyles (there is little mention of semi-nomadic groups or multilingualism, for example) before the Soviet-era demarcation of nationalities. Instead, the movie is set in a past retroactively defined in national terms, and Kurmanjan is presented as a national liberator. The most interesting (and, arguably, concerning) aspect, however, is its not-so-veiled reference to ethnic minorities and the parallels it draws with contemporary Kyrgyzstan: the movie presents the Kyrgyz as a neatly differentiated "nation" with a strong feeling of love for the motherland, thereby echoing the Soviet-era concept of a titular nation in control of a national territory. It distances itself from the Soviet idea of "friendship of the peoples" by presenting the Kyrgyz as entangled in an existential struggle against an oppressive "other", in this case identified first with the sedentary populations of the khanate of Kokand and, in the second part of the movie, with the Russian invaders. Crucially, however, the relationships with the two "others" are profoundly different.

The Kokandis, whom the audience can easily identify with the ancestors of the Uzbeks, are a sedentary people (juxtaposed against the nomadic Kyrgyz). Presented as absolute evil, they despise the Kyrgyz, and they act in a vicious, treacherous and even impious way, such as when they murder Kurmanjan's husband while he is at prayer at a holy site. Simultaneously, the Kokandis are also presented as weak and emasculated. When their leader is beaten by Kurmanjan's warriors, he is reproached with a humiliating "You were defeated by a woman!" This scene employs gendered nationalism and masculinity-based militaristic discourses on two parallel, apparently contradictory levels: on the one hand, in order to discredit the enemy, it leverages the commonly accepted idea that masculinity equals strength; on the other hand, it puts a denigrating view of women (supposedly weak and unable to prove themselves in battle) in the mouth of the enemy, by contrast emphasizing the more egalitarian and gender-inclusive nature of the Kyrgyz.

The Russians, on the other hand, are an enemy too powerful to be dealt with militarily, and Kurmanjan settles instead for peace (and the acceptance of Russian colonial rule). They are, however, enemies who respect her and the Kyrgyz, as shown in the scenes in which Kurmanjan meets with imperial officials in Saint Petersburg, with whom she can reach an agreement and coexist. ${ }^{11}$

Of the two "others" presented in the movie, the real antagonist is not the Slavic colonial invader with its alien culture and profoundly different way of life, but the similarly Turkicspeaking and Muslim, yet sedentary, populations of the Ferghana Valley. This choice of the "other" reflects a well-researched long-term shift in the identity of Kyrgyz society (Laruelle 2012; Marat 2016): while in the first years of independence the main threat for Kyrgyz identity was identified as the "cultural dilution" caused by the presence of Russian cultural and linguistic domination, even among ethnic Kyrgyz, this shifted with the tenure of President Bakiyev, whose followers started to identify the very presence of minorities, primarily Uzbek,

10 Two scenes are of special relevance in this sense: in the opening one, the narrator laments the fact that the Kyrgyz have not had a state in centuries, even though identifying the medieval "Kyrgyz khanate" with the contemporary Kyrgyz nation is a historical stretch. In another scene, Kurmanjan is seen using the Orkhon-Yenisei runic script in an effort to showcase the ancient cultural uniqueness of the Kyrgyz. This is historically impossible, however, since that kind of runic alphabet had long been forgotten by Kurmanjan's era (Pannier 2014).

11 This is not necessarily an indication of the state of Russian-Kyrgyz discursive relations on history: the drive for a re-appreciation of the history of the Kyrgyz nomads has also led to profound disagreement with Russia, especially regarding the more painful aspects of the colonial past (Rickleton 2015). 
as the main threat to Kyrgyz identity, to the Kyrgyz state, to the dominant position of the Kyrgyz and to the "purity" of the nation. ${ }^{12}$ In the years leading up to and following the 2010 ethnic massacres in Osh and Jalalabad, a strong discourse took hold in Kyrgyzstan that presented the Kyrgyz as an "endangered" people whose control over the state needs to be protected and reasserted. Even today, the Kyrgyzness of the state is seen as threatened by ethnic minorities, and a discourse of "Kyrgyzstan for the Kyrgyz" seems to be gaining hold in a context in which minorities are increasingly seen as "guests" in the home of the Kyrgyz, subject to the titular nationality's good will to accept them. Uzbek minorities are often blamed for the problems of the country and for "abusing" the benevolence of the Kyrgyz (Megoran 2013; Laruelle 2012).

I argue that within this discursive context, Kurmanjan Datka underlines and reaffirms the validity of a narrative of persecution at the hands of, and "clash of civilization" with, the Uzbeks. It marks the division between Kyrgyz and Uzbek, albeit in their historicized form, and selects national heroes based on their strict (Kyrgyz) ethnic identity, with which ethnic minorities cannot, of course, identify: Kurmanjan is not just Kyrgyz because of the language she speaks - something that could leave open the door of integration via linguistic assimilation - but mostly by virtue of her blood, family origin and lifestyle, which cannot be "learnt" or achieved. She is a hero of the Kyrgyz, and for the Kyrgyz alone.

\section{Female empowerment and gender equality}

While the first core theme of the movie, nationalism, fits perfectly with the post-Soviet articulations of national identity and related literature, the second theme is more problematic. The main character of the movie is a woman who challenges tradition, goes against the orders of the male elders, breaks free from an arranged marriage, takes direct and personal control over her life, and establishes herself as a military and political leader of a mostly patriarchal, male-dominated society by winning the respect of the men within and outside the group. The figure of Kurmanjan as a breaker of traditions is so powerful that she was even used by local NGOs as part of a communication campaign against bride kidnapping, in order to deconstruct the "traditionalist" justification behind such practice (Rickleton 2012; Следуй своему голосу! // Оз добушундан жанба! 2015). The movie Kurmanjan Datka is also a celebration of values not normally associated with "hegemonic masculinity" (see Nagel 1998:247) in a nationalist context: Kurmanjan is a hero because she avoids war with the Russians, achieving an agreement and peace rather than confrontation and conflict, as would be normal to expect in a masculinized, militarist and nationalist narrative. She is not a "Jeanne d'Arc" type of hero (i.e. a woman who embraces supposedly "virile" values, such as strength, belligerence and self-sacrifice). The director even chose to juxtapose her wisdom and conciliatory attitude with the mindless self-sacrifice of her son, as well as other male members of the tribe who decide to make a pointless attempt to resist the Russian conquest. In this sense, I argue that the "classical" image of women in nationalist discourses - being passive, subordinated to masculine hegemonic values, and relegated to the domestic sphere and as the source of members of the nation - is radically altered. In particular, the scene in which Kurmanjan allows the Russians to execute her own son in order to avoid conflict is of special importance, as it represents a radical

12 I do not deny here the existence in Kyrgyz entertainment and media of counter-discourses that emphasize ethnic coexistence, but private filmmakers usually produce such counter-discourses, often with Western government funding. See Canning 2013. 
symbolic inversion of the classical theme of the woman's role as "generator of the nation", whose duty is to produce children to fight for the collective body in times of war. Kurmanjan instead does the exact opposite, sacrificing her own son for the sake of peace instead of war. The tale in Kurmanjan Datka is therefore as much one of national struggle as it is one of female empowerment. In this sense, the movie as a political act confirms some of the topoi of gendered nationalism, but at the same time it broadly contradicts the existing literature on gender and nationalism, especially in a Central Asian context, by presenting an ultra-nationalist, restrictive and exclusionist - but simultaneously quasi-feminist - narrative.

\section{MAKING SENSE OF THE CONTRADICTION: CAN NEO-NOMADISM HELP?}

One of the ways of explaining the contradiction between the message of gender equality and that of nationalism in this example of Kyrgyz nationalist artistic expression is to expand our perspective and look at similar messages in neighbouring Turkic countries. This allows us to highlight the difference between pre-Soviet nomadic societies, which are generally believed to have featured stronger gender equality, and those with a longer history of sedentary settlement, usually assumed by foreign observers of the time and by recent scholarship alike to be more gender un-equal (Harris 1996; Kunitz 1935; Northrop 2004; in the case of the Turkmen nomads, see Edgar 2007). Meeks' (2014) sociological and anthropological research in Southern Kyrgyzstan also corroborates the hypothesis that a former nomadic lifestyle is more conducive to gender equality, a feature she explains by referring to the resilience of cultural traits. We can thus see how Kazakhstan and Kyrgyzstan, where a "neo-nomadic" revival and appreciation of the old nomadic past is taking place, give women a very different role in nationalist-themed productions.

The case of the video and photo essay How Kazakh Military Women Changed in 550 Years?, ${ }^{13}$ produced by the Kazakh Ministry of Defence on the occasion of Victory Day 2016 to display paragons of Kazakh female fighting virtue, is another interesting case of the use of typical elements of nationalist rhetoric: the quest for an ancestral state, rooting the nation's existence in a centuries-long history; the retroactive nationalization of pre-national societies; the strictly ethno-national view of identity; and, of course, the militaristic element. The video and the photo essay do, however, feature a message of female empowerment that is similar to Kurmanjan Datka, with Kazakh women presented as fierce warriors and defenders of the fatherland. Although the video does not celebrate "female" values in the same way as the movie does, and instead masculinizes women by giving them a "male" role, it also breaks the nationalist trope of the "passive/weak woman" relegated to a domestic environment. By contrast, one can look at the recent research by Polak on Uzbek cinematography to find how its portrayal of women differs profoundly from that in Kazakhstan and Kyrgyzstan. Recent massively popular, statefunded movies aimed at promoting a "nationally accepted" vision of gender roles, such as Super kelinchak (2008), have celebrated the role of women as housewives, relegated to the domestic sphere and at the service of their husband and his family. The Uzbek state-sponsored discourse ascribes women a passive role as defenders of the morality of the nation, while movies produced in the early years of independence to celebrate historical national heroes rarely featured any women in leading roles (Polak 2015). At first sight, these examples would appear to confirm the

13 See Министерство обороны РК [Ministry of Defence of Kazakhstan] 2016; for the photo essay and commentary, see KazInform 2016 and Akhal Tech Collective 2016, respectively. 
validity of a culture-based theory, centred on the importance of nomadism, as an explanatory factor for the differences between discourses.

\section{ISSUES WITH THE REFERENCE TO NEO-NOMADISM}

The immediate difference between formerly nomadic societies (Kazakhstan and Kyrgyzstan) and those with a longer sedentary tradition (Uzbekistan) within a Turkic context does not, however, fully explain the difference between the Kyrgyz-Kazakh "gender-equal-but-nationalist" message and the Uzbek "neo-traditionalist", nationalist one. ${ }^{14}$ The reference to nomadism is problematic. While it is possible to argue, as Meeks did, that nomadic heritage might make it easier to have more equal relations, its use as a discursive element does not.

First of all, it is important to bear in mind that within the broader re-appreciation of nomadic culture and heritage, there are political tendencies that consider the subordination of women to be an integral part of re-traditionalization and a crucial requirement for achieving a desired reconnection with the nomadic past. In fact, some of the most extremist admirers of the mythologized nomadic past, such as political Tengrist thinkers in Tatarstan, see female emancipation as a key sign of the decay of the noble virtues of nomadic societies (Laruelle 2007). Mongolian nationalists, for all their veneration of the nation's nomadic past, also espouse a rigidly patriarchal view of women as the property of the nation's men (Billé 2015). Neo-nomadism as a discourse can therefore easily accommodate patriarchal views on gender relations. A further indication of this appears in relation to Kyrgyzstan. Mass social issues such as non-consensual bride kidnapping are generally justified via a process of "invention of tradition", which links them back precisely to the nation's nomadic past, specifically to the Manas epos (Kleinbach, Ablezova \& Aitieva 2005; Kleinbach \& Salimjanova 2007; Werner 2009). Given the significant incidence of the phenomenon, believed to affect up to a third of women in the country (Kleinbach \& Babaiarova 2013), and the widespread support it enjoys among Kyrgyz men, especially in rural areas, it is possible to argue that, if anything, neo-nomadism works to undermine the idea of gender equality and strengthens discourses justifying patriarchal oppression. Therefore, ascribing it any role in fostering the expression of messages of female empowerment, such as the ones in Kurmanjan Datka or How Kazakh Military Women Changed in 550 Years?, becomes extremely problematic. Nomadic societies might have been more gender-equal than sedentary ones, but they were less concerned with gender equality than the Soviets. Indeed, it is against the Soviet order and its agenda of gender equality that the neo-nomadic card is played and neo-traditionalism is articulated as a rediscovery of "repressed" traditions, which generally takes the form of restriction of women rights.

\footnotetext{
14 An early remark on the preliminary version of this paper pointed at religion as a potential explanatory factor: since Uzbekistan is commonly believed to be more conservative than Kazakhstan or Kyrgyzstan, it would be normal to expect more patriarchal narratives. However, the reference to religion is problematic. First, even assuming (and being able to correctly measure) a deeper "religiousness" in Uzbek society, Kazakhstan and Kyrgyzstan also feature their own profoundly patriarchal, re-traditionalizing discourses. Secondly, because this paper looks at institutional choices behind gendered nationalist narratives, measuring the impact of religious feelings within society on institutional decision-making in non-transparent, non-democratic contexts is methodologically very difficult, if not impossible, and very problematic, as it leaves the door open for Orientalist stereotypes (among which is the assumption that Islam automatically implies a lesser role for women). Furthermore, it is hard to see how a government like Uzbekistan, characterized by a strong anti-religious agenda, would be guided by religious factors in shaping official decisions.
} 


\section{LEAVING CULTURAL ESSENTIALISM ASIDE: RATIONAL CHOICE THEORY AS AN EXPLANATORY TOOL}

By acknowledging Kurmanjan Datka as a political act, it is possible to utilize rational choice political science theory to explain why Kyrgyz institutions might be interested in throwing their weight behind a movie with such a strong message of female empowerment. This theory can also help explain why the Kazakh Ministry of Defence might have a similar interest in presenting an empowered version of the Kazakh woman in its PR campaign, a phenomenon missing from Uzbek narratives. While the lack of transparency in all three regimes, especially Kazakhstan and Uzbekistan, makes it impossible to disclose the reasoning that may have led to the development of certain discourses, it is possible to reconstruct potential explanatory factors by looking at internal regime behaviour. To this end, in this section I will adopt the theoretical framework of Bruce Bueno de Mesquita and Alastair Smith's "selectorate theory", a form of rational choice theory that focuses on the practical functioning of a political system rather than its theoretical classification (democracy, dictatorship, authoritarianism), concentrating specifically on the number of supporters needed for a regime to remain in power (Bueno de Mesquita et al. 2003; Bueno de Mesquita \& Smith 2011). In Bueno de Mesquita and Smith's (2011:5) words, these are called the "winning coalition", or "the people whose support is essential if a leader is to survive in office". Selectorate theory looks at regime survival priorities and practical political incentives behind decisions (i.e. material factors pushing politicians to make a certain choice to secure continuity of power) to understand what drives political decisions. A distinct advantage of selectorate theory over other theories is that it looks at power dynamics in a flexible way, focusing on any situation in which individuals exert power on other people, thereby allowing focus on a broad spectrum of actors involved in the production of incentives and the pressures to which political leaders of a given system have to respond.

Existing literature on nationalism in Kyrgyzstan has maintained a secondary focus on material political incentives to explain shifts in nationalist narratives. While Marat (2016) has looked at the role of moderate political forces in nuancing the nationalist drive in the country's politics, her account does not explain why a movie with such a strong nationalist message as Kurmanjan Datka was produced and funded during a time when "moderates" were in control, or why it was directed by a former deputy ombudsman of human rights (Aguilar 2014); these are two factors that suggest that "nationalist" political forces do not necessarily have a monopoly on nationalist discourses in Kyrgyzstan. Megoran (2011) has also examined the impact of nationalist ideology in shaping Bakiyev's policies, but his analysis touches only secondarily on the material political mechanisms shaping ideological orientations in the first place.

Focusing instead on the dynamics within Kazakh, Kyrgyz and Uzbek political systems, and analysing them within the framework of selectorate theory, one notes how the Kazakh and Kyrgyz systems depend on a larger base of support than the Uzbek one. On the surface, this is not immediately obvious. The democracy indices Freedom House and Polity IV classify Uzbekistan and Kazakhstan in the same category: "consolidated authoritarian regimes" in the case of Freedom House (2016) and "autocracies" for Polity IV (Marshall \& Gurr 2013). Kyrgyzstan is classified differently in both reports, however; it is considered a "semiconsolidated authoritarian regime" by Freedom House and as "democracy" by Polity IV. By contrast, this paper argues that, at least on the level of the proportion of the population that the ruling elite is accountable to, and as far as certain societal dynamics behind the support for the existing regimes are concerned, Kazakhstan and Kyrgyzstan show more similarities to each 
other than Kazakhstan and Uzbekistan. Regardless of the similarity in behaviour between the Uzbek and Kazakh political systems, Nazarbaev's regime partially relies on the support of the most economically active sectors of the population. Among these, a core place is occupied by an increasingly broad (OECD 2016), urban-based, modernized, sometimes Western-educated, rising "middle class" concentrated especially in the cities (Daly 2008), ${ }^{15}$ where the heritage of Soviet gender policies and the appeal of gender equality are arguably stronger (Shakirova 2015; Fraser \& Kim 2015). According to Shakirova (2015:213), "Equality within the family is much higher in the cities than in the countryside. [...] Urban families live according to the norms of modern Westernized societies and urban girls and women are very free and emancipated as the lifestyle in the cities becomes more and more Westernized." 16 This suggests that if Kazakh policymakers have to take the sensitivity of the middle class into account, they cannot ignore the priorities of its female component. Uzbekistan's regime, on the other hand, is a more "classical" form of authoritarianism, relying on a small support base which is rooted mostly in the power of friendly clans and solidarity groups in control of significant repressive power, and it is only concerned with the priorities of broad sectors of society on a limited scale. To frame this in relation to selectorate theory, women are not part of the winning coalition of Uzbekistan and, exactly as selectorate theory would expect, their priorities do not enter into the political equation that the regime takes into account when devising public policies. This does happen, however, to some extent, in Kazakhstan. Not surprisingly, then, women in Uzbekistan have lamented the existence of a strong governmental push towards re-traditionalization, reversing many of the achievements realized in the field of gender equality over the previous decades under Soviet rule. This is not just on a discursive level (as shown by Polak), but also in practical, everyday life matters. As argued by Constantine (2007: 115-116): "the new Uzbek woman is a young bride surrounded by relatives running the household. Karimov's government has posted significant gains in its campaign to roll back the Sovietization of Uzbek women by promoting ideals of womanhood that are either prerevolutionary or touted as such."

The relevance of political incentives becomes even clearer when Kyrgyzstan is included in the assessment. Unlike the other two countries, Kyrgyzstan is a democratizing regime, where elections are comparatively more competitive than in either Kazakhstan or Uzbekistan. In a country where the average voter turnout stands at 70.95\% (Election Guide 2017), a percentage that signals a fairly robust interest of the public in the electoral process, and where women's political activism - both peaceful and violent - has at times proven to be very influential (UNDP 2016:3-4), it only stands to reason that politicians are likely to feel the need to make at least symbolic, pandering gestures towards half of the potential electorate. Even if they exist for different reasons, there are political incentives pushing politicians to take into account the priorities of at least part of the female half of the population in Kazakhstan and Kyrgyzstan; such incentives are not present in Uzbekistan.

Moreover, both Kazakhstan and Kyrgyzstan's elites rely heavily on direct or indirect material support from external backers whose sensitivity also needs to be taken into account (or,

15 Daly (2008:5) writes, "Kazakhstan, ruled since independence by President Nursultan Nazarbayev, has made a cornerstone of its social policy to foster the development of an indigenous middle class, seeing it as a social and political guarantor of stability."

16 This paper is aware of the contradictory outcome of gender policies in Kazakhstan and their problems (Shakirova 2015; Lee 2016; Asian Development Bank 2013); however, its focus is on the existence of political incentives to produce specific policies, rather than on their fulfilment. 
one may say, pandered to), creating a further practical incentive for specific types of policymaking decisions. Kazakhstan relies on massive - and not always transparent - PR efforts ${ }^{17}$ to project onto Western public opinion the image of a modern, stable country in order to bring about friendly policies, gather support for its international initiatives (Michel 2015a; Tynan 2012; Gordon 2006; Lillis 2011; Newman \& Wright 2011), and have its sovereignty and statehood recognized in a complicated post-Crimean regional context. Following Putin's remarks on the supposed lack of historical statehood of Kazakhstan, this issue in particular has become especially serious and has spurred a number of initiatives aimed at marking the historicity of the Kazakh state (Michel 2015b; Najibullah 2014; The Astana Times 2015; Lillis 2015). Kyrgyzstan, on the other hand, is heavily reliant on international donors and arguably benefits from its ability to project an image of itself that will make it attractive to Western audiences and worthy of aid allocation. From the point of view of selectorate theory, therefore, both countries' regimes rely on what we may call an external winning coalition (in the sense of people whose support is essential for a leader to remain in power, even if they are not part of the population of the country), which is likely to take positive note of messages of female empowerment coming from state-sponsored communication. For example, judging by the success of Kurmanjan Datka in North American cultural circles, which only seem to have noticed the film's message of female empowerment (telling examples are provided by Vasquez 2014; Kelly 2014; Rose 2014; Tremblay 2014; ${ }^{18}$ Aguilar 2014) but not its nationalistic background, the communication strategy behind the movie seems to have worked.

\section{CONCLUSIONS}

Looking at the structure of political incentives in a given political system through the framework of selectorate theory allows observation of the specific mechanisms that drive politicians' decisions, including questions such as what kind of public relations programmes to finance or what movie projects deserve state-supported funding. This helps explain why, regardless of differences in the classification of their regime type and of similarities in their (Turkic) cultural background and internal nationalist rhetoric, political elites and institutions react to different kinds of incentives by deploying different discourses on gender roles within broader nationalist narratives. In both a non-democratic country such as Kazakhstan and a democratizing country such as Kyrgyzstan, practical reasons behind regime survival ensure that the leadership feels incentivized to promote a discourse that presents women in a more emancipated role. In a nondemocratic country such as Uzbekistan, by contrast, which "works" on the basis of different practical mechanisms than Kazakhstan, the political elite does not perceive the same kind of pressure and therefore indulges in a more "traditional" nationalist discourse when it comes to gender relations. The case studies analysed in this paper show how the combined employment of two theoretical tools - rational choice theory on the one hand and literature on nationalist discourses on the other hand - can contribute to an understanding of unconventional forms of discourses on gender relations, which each theoretical tool alone would be unable to explain.

17 For an example of pro-Kazakh PR, see Eisele 2013. On the alleged efforts of the Kazakh government to influence Wikipedia, see Wikipediocracy 2013.

18 Tremblay describes the movie as "imposant et instructif", but curiously calls the Kyrgyz a "clan mongol" and claims that Datka strove to "conserver un peu d'indépendance au Kirghizistan", a polity that did not exist until the proclamation of the Kara-Kirghiz Autonomous Oblast in 1924. 
While the literature on gendered nationalist discourses holds mostly true across a wide range of contexts, the cases analysed in this paper show that nationalist yet simultaneously femaleempowering (if not, as in the case of Kurmanjan Datka, quasi-feminist) messages are possible, if and when specific types of political incentives exist. The contradictory dichotomy of female empowerment and exclusivist ethnic-based nationalism emerging from Kurmanjan Datka and the How Kazakh Military Women Changed in 550 Years? video and photo essay prove that a connection can be established between the internal functioning of political systems on the one hand and gender narratives emerging within nationalist discourses on the other, independent of the regime's nominal classification. Rather than the mere existence of nationalist ideas within a political body, what seems to make the appearance of nationalist discourses that marginalize women more or less likely is the amount of political incentives in place within a political body, forcing decision-makers to take into account the desires of specific internal or external gendersensitive constituencies.

\section{REFERENCES}

AdAms, Laura L. 2010. The Spectacular State: Culture and National Identity in Uzbekistan. Durham: Duke University Press.

Agullar, Carlos 2014. Changing History: Sadyk Sher-Niyaz on 'Kurmanjan Datka: Queen of the Mountains'. IndieWire, 2 Dec. 2014. Online: <indiewire.com/2014/12/changing-history-sadyk-sher-niyaz-onkurmanjan-datka-queen-of-the-mountains-171755/>, accessed 20 Jan. 2017.

Akbarzadeh, Shahram 1996. Nation-Building in Uzbekistan. Central Asian Survey 15(1): 23-32.

Akhal Tech Collective 2016. Kazakhstan's Defence Ministry Shows How the Country's Women in Arms Have Changed Through the Ages. Global Voices, 3 May 2016. Online: <globalvoices.org/2016/05/03/kazakhstans-defenceministry-shows-how-the-countrys-women-in-arms-have-changed-through-the-ages/>, accessed 15 June 2016.

Arendt, Hannah 1962. The Origins of Totalitarianism. Cleveland: The World Publishing Company.

Asian Development Bank 2013. Kazakhstan: Country Gender Assessment. Mandaluyong City: ADB.

BILlÉ, Franck 2015. Nationalism, Sexuality and Dissidence in Mongolia. In: M. McLelland \& V. Mackie (eds), Routledge Handbook of Sexuality Studies in East Asia: 162-173. NY: Routledge.

Bueno de Mesquita, Bruce, Alastair Smith, Randolph M. Siverson \& James D. Morrow 2003. The Logic of Political Survival. Cambridge, MA: The MIT Press.

Bueno de Mesquita, Bruce \& Alastair Smith 2011. The Dictator's Handbook: Why Bad Behaviour is Almost Always Good Politics. NY: Public Affairs.

CAnning, Emily 2013. Not Your Babushka's Serial: Kyrgyzstan's Hit New Show Dorm. Registan.net, 9 July 2013. Online: <registan.net/2013/07/09/not-your-babushkas-serial-kyrgyzstans-hit-new-show-dorm/>, accessed 30 June 2016.

CAnning, Emily 2014. The Two Films Inside Kyrgyzstan's 'Kurmanjan Datka'. Radio Free Europe - Radio Liberty, 30 Dec. 2014. Online: <rferl.org/a/kurmanjan-datka-queen-of-the-mountains-kyrgyzstan-film/26769501.html>, accessed 29 June 2016.

Constantine, Elizabeth A. 2007. Practical Consequences of Soviet Policy and Ideology for Gender in Central Asia and Contemporary Reversal. In: J. SAHAdeo \& R. ZANCA (eds), Everyday Life in Central Asia: 115-126. Bloomington: IU Press.

DALY, John C.K. 2008. Kazakhstan's Emerging Middle Class: Silk Road Paper 2008. Washington D.C: Central AsiaCaucasus Institute. Online: <isdp.eu/content/uploads/publications/2008_daly_kazakhastans-emergingmiddle-class.pdf>, accessed 1 Feb. 2017.

Edgar, Adrienne 2007. Everyday Life among the Turkmen Nomads. In: J. SAhadeo \& R. Zanca (eds), Everyday Life in Central Asia: 37-44. Bloomington: IU Press.

Eisele, Al 2013. Kazakhstan: Image vs. Reality. The Huffington Post, 15 July 2013. Online: < huffingtonpost.com/ al-eisele/kazakhstan-image-vs-reali_b_3601075.html>, accessed 5 July 2016. 
Election Guide 2017. Kyrgyzs Republic. Online: <electionguide.org/countries/id/117/>, accessed 3 Mar. 2019.

Fedorenko, Vladimir 2012. Central Asia: From Ethnic to Civic Nationalis. Washington D.C: Rethink Institute.

Fox, Jo 2014a. Atrocity Propaganda. British Library World War One Project. Online: <bl.uk/world-war-one/articles/ atrocity-propaganda>, accessed 10 Feb. 2017.

Fox, Jo 2014b. Women in World War One Propaganda. British Library World War One Project. Online: $<$ bl.uk/world-war-one/articles/women-in-world-war-one-propaganda>, accessed 10 Feb. 2017.

Fraser, Giles \& Marina KIM 2015. Welcome to Astana, Kazakhstan: One of the Strangest Capital Cities on Earth. The Guardian, 28 July 2015. Online: <theguardian.com/cities/2015/jul/28/astana-kazakhstan-strangestcapital-cities-on-earth>, accessed 17 Jan. 2017.

Freedom House 2012. Methodology. Nations in Transit 2012. Online: <freedomhouse.org/report/nationstransit-2012/methodology>, accessed 3 Aug. 2016.

Freedom House 2016. Nations in Transit 2016. Online: <freedomhouse.org/sites/default/files/FH_NIT2016_Final_ FWeb.pdf>, accessed 21 Jan. 2017.

Gordon, Scott 2006. Kazakhstan Fights Borat Image with PR Largesse. A.V. Club, 28 Sept. 2006. Online: $<$ avclub.com/article/kazakhstan-fights-borat-image-with-pr-largesse-16032>,_accessed 4 July 2016.

GuPTA, Charu 1991. Politics of Gender: Women in Nazi Germany. Review of Women's Studies 26(17):40-48.

Harris, Colette 1996. Women of the Sedentary Population of Russian Turkestan through the Eyes of Western Travellers. Central Asian Survey 15(1): 75-95.

Ibraimov, Bakyt 2014. Kyrgyzstan's Biggest Ever Blockbuster Hits Cinemas Amid Patriotism Push. The Guardian, 24 Aug. 2014. Online: <theguardian.com/world/2014/aug/24/kyrgyzstan-blockbuster-hits-cinemas-patriotismpush-taxpayers-money>, accessed 15 June 2016.

IsHKANIAN, Armine 2004. Gendered Transitions: The Impact of the Post-Soviet Transition on Women in Central Asia and the Caucasus. In: M.P. Amineh \& H. Houweling (eds), Central Eurasia in Global Politics: Conflict, Security and Development:161-182. (International Studies in Sociology and Social Anthropology 92) Leiden: Brill.

Jenson, Robert W. 1994. On Hegemonic Discourse. First Things, Aug. 1994.

KandiYoti, Deniz 1991. Identity and Its Discontents: Women and the Nation. In: P. Williams \& L. Chrisman (eds), Colonial Discourse and Post-Colonial Theory: A Reader:376-391. NY: Columbia University Press.

Kandiyoti, Deniz 2007. The Politics of Gender and the Soviet Paradox: Neither Colonized, Nor Modern? Central Asian Survey 26(4): 601-623.

KazInform 2016. How Kazakh Military Women Changed in 550 Years? KazInform International News Agency, 3 May 2016. Online: <inform.kz/en/how-kazakh-military-women-changed-in-550-years-photo-video_a2899537>, accessed 3 June 2016.

Kelly, Brendan 2014. Kurmanjan Datka: Uncomfortable Truths and the Fight for Independence. Montreal Gazette, 22 Aug. 2014. Online: <montrealgazette.com/entertainment/movie-guide/Kurmanjan+Datka+Uncomfortable+ truths+fight+independence/10141307/story.html>, accessed 8 Feb. 2017.

KesICI, Özgecan 2011. The Dilemma in the Nation-Building Process: The Kazakh or Kazakhstani Nation? Journal of Ethnopolitics and Minority Issues in Europe 10(1):31-58.

Kleinbach, Russell, Mehrigiul Ablezova \& Medina Aitieva 2005. Kidnapping for Marriage (Ala kachuu) in a Kyrgyz Village. Central Asian Survey 24(2): 191-202.

Kleinbach, Russell \& Gazbubu Babaiarova 2013. Reducing Non-Consensual Bride Kidnapping in Kyrgyzstan. Eurasian Journal of Social Sciences 1(1): 50-60.

Kleinbach, Russell \& Lilly Salimjanova 2007. Kyz ala kachuu and adat: Non-Consensual Bride Kidnapping and Tradition in Kyrgyzstan. Central Asian Survey 26(2):217-233.

Kосн, Natalie 2011. Security and Gendered National Identity in Uzbekistan. Gender, Place and Culture 18(4): 499-518. Kunitz, Joshua 1935. Dawn Over Samarkand: The Rebirth of Central Asia. NY: International Publishers.

Kurzman, Charles 1999. The Invention of Nationalism in an Invented Nation. Critique 15:77-98.

Laruelle, Marlène 2007. Religious Revival, Nationalism and the 'Invention of Tradition': Political Tengrism in Central Asia and Tatarstan. Central Asian Survey 26(2): 203-216.

Laruelle, Marlène 2012. The Paradigm of Nationalism in Kyrgyzstan: Evolving Narrative, the Sovereignty Issue, and Political Agenda. Communist and Post-Communist Studies 45:39-49. 
LeE, Dimitry 2016. Kazakhstan Makes Strides in Gender Equality: Issues of Labour Inclusion and Violence Remain. The Astana Times, 10 Dec. 2016. Online: <astanatimes.com/2016/12/kazakhstan-makes-strides-in-genderequality-issues-of-labour-inclusion-and-violence-remain/>, accessed 6 Feb. 2017.

LeliK, Anna 2014. Kyrgyz Moviegoers Push Local Blockbuster with Social Media. Eurasianet, 17 Sept. 2014. Online: <eurasianet.org/node/70026, accessed 4 June 2016.

Lieven, Anatol 1994. The Baltic Revolution: Estonia, Latvia, Lithuania and the Path to Independence. New Haven: YUP.

Lillis, Joanna 2011. Britain's Master of Spin to Burnish Kazakhstan's Image. Eurasianet, 24 Oct. 2011. Online: $<$ eurasianet.org/node/64361>, accessed 5 July 2016.

LiLlis, Joanna 2015. Kazakhstan Celebrates Statehood in Response to Russia. Eurasianet, 6 Jan. 2011. Online: <eurasianet.org/node/71536>, accessed 12 Jan. 2017.

Marat, Erica 2016. We Disputed Every Word: How Kyrgyzstan's Moderates Tame Ethnic Nationalism. Nations and Nationalism 22(2):305-324.

Marshall, Monty G. \& Ted R. Gurr 2013. Polity IV Project: Political Regime Characteristics and Transitions, 1800-2013. Online: <systemicpeace.org/polity/polity4.htm>, accessed 5 Jan. 2017.

Martin, Terry 2001. The Affirmative Action Empire: Nations and Nationalism in the Soviet Union, 1923-1939. Ithaca: Cornell University Press.

Meeks, Robyn 2014. Culture and the Persistence of Gender Roles in Central Asia: Evidence Through Natural Experiments on Spillovers and Women's Empowerment. Working Paper, University of Michigan.

Megoran, Nick 2002. The Border of Eternal Friendship? The Politics and Pain of Nationalism and Identity along the Uzbekistan-Kyrgyzstan Ferghana Valley Boundary, 1999-2000. PhD Dissertation, Cambridge University.

Megoran, Nick 2008. Framing Andijon, Narrating the Nation: Islam Karimov's Account of the Events of 13 May 2005. Central Asian Survey 27(1): 15-31.

Megoran, Nick 2011. Rethinking the Study of International Boundaries: A Biography of the Kyrgyzstan-Uzbekistan Boundary. Annals of the Association of American Geographers 102(X): 1-18.

Megoran, Nick 2013. Shared Space, Divided Space: Narrating Ethnic Histories of Osh. Environment and Planning 35: 892-907.

Michel, Casey 2015a. Tony Blair Has Another Repressive Central Asian Autocracy to Sell You. New Republic, 6 Jan. 2015. Online: <newrepublic.com/article/120691/tony-blair-does-pr-repressive-azerbaijan-kazakhstanautocracies>, accessed 9 July 2016.

Michel, Casey 2015b. Take Note, Putin: Kazakhstan Celebrates 550 Years of Statehood. The Diplomat, 14 Sept. 2015. Online: <thediplomat.com/2015/09/take-note-putin-kazakhstan-celebrates-550-years-of-statehood/>, accessed 10 Feb. 2017.

Министерство обороны РК [Ministry of Defence of Kazakhstan] 2 May 2016. Как менялась женщина-воин в течение 550 лет казахской истории [How Kazakh Military Women Changed in 550 Years] [Online video]. $<$ youtube.com/watch?v=NbRKX71JZZE $>$, accessed 3 May 2016.

NAGEL, Joane 1998. Masculinity and Nationalism: Gender and Sexuality in the Making of Nations. Ethnic and Racial Studies 21(2): 242-269.

NaJibullah, Farangis 2014. Putin Downplays Kazakh Independence, Sparks Angry Reaction. Radio Free Europe Radio Liberty, 3 Sept. 2014. Online: <rferl.org/a/kazakhstan-putin-history-reaction-nation/26565141.html>, accessed 15 Mar. 2015.

Newman, Melanie \& Oliver Wright 2011. Kazakhstan: PR Firm's Plan to Target Sting after Gig Boycott. The Independent, 8 Dec. 2011. Online: <independent.co.uk/news/uk/politics/kazakhstan-pr-firms-plan-totarget-sting-after-gig-boycott-video-6273824.html>, accessed 6 July 2016.

Northrop, Douglas T. 2004. Veiled Empire: Gender and Power in Stalinist Central Asia. Ithaca: Cornell University Press.

OECD 2016. Multi-Dimensional Review of Kazakhstan, OECD Publishing. Online: < keepeek.com/Digital-AssetManagement/oecd/development/multi-dimensional-review-of-kazakhstan/the-emergence-of-the-middleclass-in-kazakhstan_9789264246768-graph10-en\#.WJRiBbaLRE4>, accessed 24 Jan. 2017.

Ormiston, Rosalind \& Gary Sheffield 2013. First World War Posters. London: Flame Tree Publishing.

Pannier, Bruce 2014. Who Was Kurmanjan Datka And What Does She Mean To The Kyrgyz People?", Radio Free Europe - Radio Liberty, 31 Dec. 2014. Online: <rferl.org/a/qishloq-ovozi-who-was-kurmanjandatka/26770979.html>, accessed 1 June 2016. 
Peterson, V. Spike 1994. Gendered Nationalism. Peace Review 6(1): 77-83.

PolaK, Ewa 2015. Women, Nation and Anti-Sovietism: Pop Culture in the Service of O'zbekchilik. Presentation at the conference Orientalism, Colonial Thinking and the Former Soviet Periphery, Vilnius University, 2015.

Rickleton, Chris 2012. Kyrgyzstan: Civic Initiatives Seek to Tackle Bride-Kidnapping. Global Voices, 1 June 2012. Online: >globalvoices.org/2012/06/01/kyrgyzstan-civic-initiatives-seek-to-tackle-bride-kidnapping/>, accessed 4 Sept. 2016.

Rickleton, Chris 2015. Kyrgyzstan Risks Riling Russia with Tribute to Historical Tragedy. Eurasianet, 22 June 2015. Online: <eurasianet.org/node/73961>, accessed 24 Oct. 2016.

Rose, Alex 2014. The Best of the World Film Fest 2014. Cult MTL, 20 Aug. 2014. Online: <cultmontreal.com/2014/08/ the-best-of-the-world-film-fest-2014/>, accessed 7 Feb. 2017.

SHAKIROVA, Svetlana 2015. Gender Equality in Kazakhstan and the Role of International Actors in Its Institutionalization. In: Y. Gradskova \& S. SANDers (eds), Institutionalizing Gender Equality: Historical and Global Perspectives: 211-225. London: Lexington.

Следуй своему голосу! // Оз добушундан жанба! [Follow your voice] 7 May 2015. Birth of the Legend: PSA against Bride Kidnapping in Kyrgyzstan [Online video]. <youtube.com/watch?v=PS5EZkrquLk>, accessed 14 July 2016.

SLezkine, Yuri 1994. The USSR as a Communal Apartment, or How a Socialist State Promoted Ethnic Particularism. Slavic Review 53(2): 414-452.

Stoddart, Mark C.J. 2007. Ideology, Hegemony, Discourse: A Critical Review of Theories of Knowledge and Power. Social Thought and Research 28: 191-225.

The Astana Times 2015. Why Celebrate 550 Years of Kazakh Statehood? The Astana Times, 28 Jan. 2015. Online: <astanatimes.com/2015/01/celebrate-550-years-kazakh-statehood/>, accessed 12 Jan. 2017.

Thibault, Hélène 2016. Female Virtue, Religion and State Ideology in Tajikistan. CERIA Briefs 10. Online: $<$ centralasiaprogram.org/blog/2016/01/04/female-virtue-religion-and-state-ideology-in-tajikistan/>, accessed 7 July 2016.

Tremblay, Odile 2014. 38e festival des films du monde: Le bon grain et l'ivraie. Le Devoir, 23 Aug. 2014. Online: $<$ ledevoir.com/culture/cinema/416663/38e-festival-des-films-du-monde-le-bon-grain-et-1-ivraie>, accessed 8 Feb. 2017.

TynAn, Deirdre 2012. Kazakhstan: Top-Notch PR Firms Help Brighten Astana’s Image. Eurasianet, 18 Jan. 2012. Online: <eurasianet.org/node/64860>, accessed 9 July 2016.

UNDP 2016. Case Study on Combating Gender Inequality in Political Participation in Kyrgyzstan. Regional Human Development Report 2016. Online: <kg.undp.org/content/dam/kyrgyzstan/Publications/gender/ Case\%20study_Eng10Oct2016.pdf>, accessed 5 Nov. 2018.

Vasquez, Gordon 6 Nov. 2014. Sharon Stone, Kurmanjan Datka Queen of the Mountains, Abigal Fraher. [Online video]. <youtube.com/watch?v=gZWDy4V-7h0>, accessed 13 May 2016.

Werner, Cynthia 2009. Bride Abduction in Post-Soviet Central Asia: Making a Shift Towards Patriarchy Through Local Discourses of Shame and Tradition. The Journal of the Royal Anthropological Institute 15(2):314-331.

Wikipediocracy 2013. Jimmy Wales, Kazakhstan, Tony Blair and Wikipedia: A Timeline. Wikipediocracy. Online: $<$ wikipediocracy.com/2013/01/02/jimmy-wales-kazakhstan-tony-blair-and-wikipedia-a-timeline/ $>$, accessed 9 July 2016 . 